Acta vet. scand. $1986,27,584-597$.

From the Department of Microbiology and Immunology, Norwegian College of Veterinary Medicine, Oslo and the State Veterinary Laboratory for Northern Norway, Harstad, Norway.

\title{
CORYNEBACTERIUM PSEUDOTUBERCULOSIS INFECTION IN GOATS II.
}

\author{
THE PREVALENCE OF CASEOUS LYMPHADENITIS \\ IN 36 GOAT HERDS IN NORTHERN NORWAY
}

\author{
By \\ Gudmund Holstad
}

\begin{abstract}
HOLSTAD, G.: Corynebacterium pseudotuberculosis infection in goats II. The prevalence of caseous lymphadenitis in 36 goat herds in Northern Norway. Acta vet. scand. 1986, 27, 584-597. - The precalence of caseous lymphadenitis was surveyed in 36 goat herds in Northern Norway. In each herd, information concerning the occurrence of the disease was obtained from the farmer. Adult animals (1 year of age or older) in 35 herds were examined for superficial swellings, and serum samples were collected from most animals in the herds. The sera were examined for antibodies to Corynebacterium pseudotuberculosis using the bacterial agglutination test (BAT) and the hemolysis inhibition test (HIT).

Caseous lymphadenitis was diagnosed with certainty in 19 herds. Information from the farmers indicated that the disease indeed occurred in these herds, and that the majority had been infected with the disease for many years. The herds had apparently become infected through contact with animals from infected herds. Clinical examinations were carried out in 18 of these herds and superficial swellings were found in $26 \%$ of the examined animals. The prevalence of animals with lesions varied from 11 to $40 \%$ among the herds. Of the animals in these herds, $81 \%$ were positive in BAT and $84 \%$ in HIT. The prevalence of positive animals varied from 26 to $99 \%$ in BAT and 28 to $99 \%$ in HIT. The prevalence of seropositive animals was lowest in a herd in which animals were kept separately in stalls.

Caseous lymphadenitis could not be diagnosed in 16 herds. Information from the farmers indicated that the disease indeed seemed to be absent in 14 of these herds. These 14 herds had no history of contact with animals from herds considered to be infected. However, in the remaining 2 herds, the farmers were somewhat uncertain about the occurrence of the disease. One of these 2 herds had a history of contact with infected herds through participation in a goat "breeding circle". Only a few of the animals were, however, seropositive and all these had low antibody titres.

In 1 newly established herd, a single animal showed a high positive titre in BAT only. All the other animals were negative in both tests. This particular herd consisted of animals obtained both from herds with caseous lymphadenitis and from herds in which the disease was not considered to occur.
\end{abstract}


serologicalexaminations; clinical examinations; bacteriologicalexaminations.

Caseous lymphadenitis caused by Corynebacterium pseudotuberculosis is a common disease in goat herds in Norway. The disease is characterized by superficial swellings, especially in lymph nodes. Affected animals are usually apparently healthy. Occasionally the disease becomes generalized with abscess formation in many organs (Renshaw et al. 1979, East 1982). Lesions affecting throat, trachea and bronchia occasionally cause respiratory distress and choking. In Norway, however, few animals are culled or die as a result of the disease.

Caseous lymphadenitis is reported as being a common cause of carcass condemnation in sheep (Marsh 1965). Abscesses are often found in carcasses from goats during meat inspection in Norway (Ribe, personal communication). In a meat inspection survey of 3720 goats in Australia, Hein \& Cargill (1981) found that $7 \%$ of the carcasses had abscesses.

Few epidemiological surveys of caseous lymphadenitis in goats have been reported. Lund et al. (1982) examined serum samples from a dairy goat herd in Norway and demonstrated antibodies to C. pseudotuberculosis in most animals. Ashfaq \& Campbell (1979) collected information from goat farmers in USA and reported that superficial abscesses were found in $8 \%$ of 4013 animals. Burrell (1981) carried out clinical and serological examinations of goats in 2 herds in Australia and demonstrated caseous lymphadenitis in both herds.

The purpose of the present work was to study the distribution of caseous lymphadenitis in some goat herds in Northern Norway, a region in which goat milk production is an important farming activity.

\section{Herds}

\section{MATERIALS AND METHODS}

A survey of the prevalence of caseous lymphadenitis in 36 goat herds in the counties of Nordland and Troms was carried out during the period March-May 1981. Fig. 1 presents the geographical distribution of the herds. Altogether 17 of these herds were members of goat "breeding circles"1. Herds 1, 6, 7, 10, 11,

1 Breeding system practised in Norway in which several herds share the use of the same breeding males. 
14, 16, 19 and 21 constituted one "breeding circle". Herds 31 and 32 were members of another "breeding circle", while Herds 25, 26, 28, 30, 35 and 36 comprised a third.

The number of adult animals (1 year of age or older) in each herd varied from 29 to 106 . There was no male breeding animal in 8 herds while the number of breeding males in each of the other herds varied from 1 to 3 .

In Herds 17 and 36, lactating goats were placed singly in stalls. In the remaining herds, the lactating goats were placed in pens. The males were placed singly in stalls in all herds. In 34 of the herds, animals were housed indoors in the winter but allowed to graze during the daytime in the summer (June-September). In the remaining 2 herds, animals were housed indoors throughout the year.

In most herds, the kids were born in January and February. In one herd most kids were born in November, while in another herd, most kids were born in March and April.

\section{Anamnestic information}

In each herd, data concerning the occurrence of the disease and contact with herds considered to be infected were collected from the farmer. Farmers who said that the disease did occur in their herds were asked how and when they thought the herds became infected. These farmers were also asked to describe the manifestation of the disease in the herd after infection.

\section{Clinical examinations}

Altogether 2428 adult animals, 2382 females and 46 males, were examined. In 35 herds most animals were examined while no animal was examined in 1 herd (Herd 19).

Clinical examinations were carried out by inspection and palpation. The sites at which superficial swellings were present were registered. Swellings on the shoulder and chest were, however, excluded as lesions at these sites were considered to be granulomas arising after vaccination against paratuberculosis.

\section{Bacteriological examinations}

Pus samples were collected from open superficial abscesses from 33 animals. One goat with an abscess in ln. tracheobronchales was killed and pus collected from the abscess. The 34 animals came from 15 herds. 
Samples were collected on swabs and stored for up to 2 days in Stuart's medium. The material was cultured on blood agar (Blood agar base with $7 \%$ bovine erythrocytes) and incubated both aerobically and anaerobically for $48 \mathrm{~h}$ at $37^{\circ} \mathrm{C}$. Any bacteria isolated were identified according to standard bacteriological principles (Buchanan \& Gibbons 1974).

\section{Serological examinations}

Sera from 2458 adult animals, 2412 females and 46 males, were examined. Blood samples were collected from most of the animals in each herd on the same day as the clinical examination. Sera were prepared according to standard procedures and stored at $-20^{\circ} \mathrm{C}$. All the sera were examined for antibodies to C. pseudotuberculosis in both the bacterial agglutination test (BAT) and the hemolysis inhibition test (HIT) (Holstad 1986a).

\section{RESULTS}

In Table 1, the herds are listed together with details of the information provided by farmers concerning the occurrence of caseous lymphadenitis. The results from the clinical and serological examinations are also given.

On the basis of information from the farmers, the herds were classified into the following 3 groups: Infected herds (Herds $1-$ 19), herds in which the presence of infection was considered uncertain (Herds 20-22), and non-infected herds (Herds 2336 ). In the following, these 3 groups will be considered separately.

Infected herds (Herds 1-19)

The results from the clinical, bacteriological and serological examinations are presented in Tables $1,2,3$ and 4 .

According to the farmers, caseous lymphadenitis was introduced in 18 of these 19 herds through kids or adult animals being obtained from other herds. In 1 herd, the farmer reported that the animals had become infected at pasture. All the 19 herds had a history of contact with other herds considered to be infected. In 2 herds, caseous lymphadenitis had been seen for the first time during the 2 years prior to the start of the present investigation. In the remaining herds the disease had existed for at least several years, in some cases having been present since the herds had been established. 
T a b l e 1. Thirty-six goat herds surveyed for the presence of caseous lymphadenitis. Information from the farmers, and results of the clinical and serological examinations.

\begin{tabular}{|c|c|c|c|c|c|}
\hline \multirow[t]{2}{*}{$\begin{array}{c}\text { Herd } \\
\text { no. }\end{array}$} & \multirow{2}{*}{$\begin{array}{l}\text { No. of animals } \\
\text { examined } \\
\text { clinically/ } \\
\text { serologically }\end{array}$} & \multirow[t]{2}{*}{$\begin{array}{l}\text { Information } \\
\text { from } \\
\text { the farmer }\end{array}$} & \multirow[t]{2}{*}{$\begin{array}{l}\text { Animals (\%) } \\
\text { with superfic. } \\
\text { swellings }\end{array}$} & \multicolumn{2}{|c|}{$\begin{array}{c}\text { Animals }(\%) \\
\text { positive }\end{array}$} \\
\hline & & & & BAT & HIT \\
\hline 1 & $40 / 40$ & + & 40 & 63 & 68 \\
\hline 2 & $89 / 89$ & + & 36 & 75 & 79 \\
\hline 3 & $91 / 91$ & + & 35 & 98 & 98 \\
\hline 4 & $94 / 94$ & + & 33 & 93 & 97 \\
\hline 5 & $87 / 87$ & + & 31 & 55 & 64 \\
\hline 6 & $69 / 69$ & + & 30 & 99 & 91 \\
\hline 7 & $80 / 80$ & + & 30 & 98 & 96 \\
\hline 8 & $84 / 83$ & + & 26 & 90 & 96 \\
\hline 9 & $62 / 62$ & + & 26 & 79 & 77 \\
\hline 10 & $76 / 76$ & + & 24 & 93 & 99 \\
\hline 11 & $79 / 78$ & + & 24 & 78 & 83 \\
\hline 12 & $73 / 73$ & + & 23 & 97 & 97 \\
\hline 13 & $106 / 106$ & + & 23 & 92 & 98 \\
\hline 14 & $66 / 66$ & + & 23 & 52 & 65 \\
\hline 15 & $66 / 66$ & + & 17 & 74 & 74 \\
\hline 16 & $97 / 97$ & + & 14 & 67 & 75 \\
\hline 17 & $43 / 43$ & + & 12 & 26 & 28 \\
\hline 18 & $74 / 73$ & + & 11 & 85 & 88 \\
\hline 19 & $0 / 43$ & + & ** & 84 & 86 \\
\hline 20 & $46 / 46$ & $?$ & 2 & 0 & 0 \\
\hline 21 & $48 / 48$ & $?$ & 0 & 0 & 0 \\
\hline 22 & $57 / 57$ & $?$ & 4 & 2 & 0 \\
\hline 23 & $51 / 51$ & - & 4 & 0 & 0 \\
\hline 24 & $46 / 46$ & - & 4 & 0 & 0 \\
\hline 25 & $59 / 59$ & - & 2 & 0 & 0 \\
\hline 26 & $75 / 75$ & - & 1 & 7 & 4 \\
\hline 27 & $89 / 81$ & - & 1 & 0 & 0 \\
\hline 28 & $73 / 73$ & - & 0 & 4 & 0 \\
\hline 29 & $39 / 39$ & - & 0 & 3 & 0 \\
\hline 30 & $94 / 92$ & - & 0 & 1 & 0 \\
\hline 31 & $96 / 96$ & - & 0 & 0 & 0 \\
\hline 32 & $94 / 94$ & - & 0 & 0 & 0 \\
\hline 33 & $72 / 72$ & - & 0 & 0 & 0 \\
\hline 34 & $48 / 48$ & - & 0 & 0 & 0 \\
\hline 35 & $36 / 36$ & - & 0 & 0 & 0 \\
\hline 36 & $29 / 29$ & - & 0 & 0 & 0 \\
\hline
\end{tabular}

+ : Caseous lymphadenitis occurs.

?: The farmer uncertain about the occurrence of caseous lymphadenitis.

-: Caseous lymphadenitis does not occur.

${ }^{*}$ : $\quad$ No animal examined clinically.

1) Bacterial agglutination test.

2) Hemolysis inhibition test. 
T a b l e 2. Localization of superficial swellings in 352 animals in infected herds, in 3 animals in uncertain herds and in 7 animals in non-infected herds.

\begin{tabular}{lccc}
\hline Localization* & $\begin{array}{c}\text { Infected herds } \\
\text { No. } \% \text { of animals }\end{array}$ & $\begin{array}{c}\text { Uncertain herds } \\
\text { No. of animals }\end{array}$ & $\begin{array}{c}\text { Non-infected herds } \\
\text { No. of animals }\end{array}$ \\
\hline $\begin{array}{l}\text { Lnn. mandibulares } \\
\text { Lnn. parotidei }\end{array}$ & $86(24)$ & 1 & 1 \\
Throat & $79(22)$ & & \\
Neck-Lnn. cervicales & $35(10)$ & & \\
$\quad$ & & & \\
$\quad$ superficiales & $96(27)$ & 1 & 1 \\
Lnn. Other places & $13(4)$ & 1 & 2 \\
Lnn. popliteus & $44(13)$ & & 3 \\
Udder/Lnn. mammarii & $31(9)$ & & \\
Other places & $4(1)$ & & \\
\hline
\end{tabular}

* When lymph nodes are given: Superficial swellings are localized in or close to these on one or both sides.

Some farmers reported that the disease had been most troublesome during the first few years after the herd had become infected, while other farmers said that the disease problems had been almost constant.

Superficial swellings were demonstrated in $26 \%$ of the examined animals. The prevalence of animals with lesions varied from 11 to $40 \%$ in the different herds. Superficial swellings were found in $26 \%$ of the females and $17 \%$ of the males. Most lesions were localized in, or close to, superficial lymph nodes (Table 2). Altogether $87 \%$ of the clinically affected animals had swellings in the head and neck region. In $11 \%$ of the affected animals, swellings were found in two or three of the locations presented

T a ble 3. Results from bacteriological examination of abscesses from 31 animals from 13 infected herds.

\begin{tabular}{lc}
\hline Bacteria isolated & No. of animals \\
\hline C. pseudotuberculosis in pure culture & 15 \\
C. pseudotuberculosis in mixed culture & 10 \\
C. pyogenes in pure culture & 1 \\
S. aureus in pure culture & 1 \\
Micrococcus sp. in pure culture & 1 \\
Proteus sp. in pure culture & 1 \\
C. pyogenes and S. aureus in mixed culture & 1 \\
C. pyogenes, Bacillus sp. & 1 \\
and Streptococcus sp. in mixed culture & \\
\hline
\end{tabular}


in Table 2. Moreover, in some animals, swellings were present in, or close to, the corresponding lymph node on both sides. Pus samples from 31 animals (from 13 herds) were examined bacteriologically (Table 3). C. pseudotuberculosis being isolated from 25 .

The results of the serological examinations are presented in Tables 1 and 4 . Table 4 shows that sera from $88 \%$ of the animals were positive in either one or both tests. In all, $94 \%$ of the animals with superficial swellings were positive in either BAT or HIT or both tests, the corresponding figure for animals with no such lesions being $83 \%$.

Herds in which the presence of infection was considered uncertain (Herds 20-22)

The results of the clinical and serological examinations of animals from these herds are shown in Tables 1 and 2. According to the farmer, animals in Herd 20 had possibly been in contact with an infected herd during the summer and autumn prior to the start of the investigation. Herd 21 was member of a "breeding circle" in which herds considered to be infected also participated.

Herd 22 was newly established, and animals had been obtained both from infected herds and herds considered to be free from caseous lymphadenitis. In this herd, no animal was older than 1 year of age. Two animlas had superficial swellings, but sera from these animals were negative in both BAT and HIT. One of the animals without swellings, however, had a high positive titre in BAT.

T a b le 4. Results from serological examinations using the bacterial agglutination test (BAT) and hemolysis inhibition test (HIT) in infected herds.

\begin{tabular}{|c|c|c|c|c|}
\hline \multirow{2}{*}{ Animals } & \multirow{2}{*}{$\begin{array}{c}\text { No. of } \\
\text { animals }\end{array}$} & \multicolumn{3}{|c|}{ Percentage of animals positive in } \\
\hline & & BAT & HIT & BAT and/or HIT \\
\hline Total & 1416 & $81(26-99)^{*}$ & $84(28-99)^{*}$ & 88 \\
\hline Females & 1393 & 81 & 85 & 88 \\
\hline Males & 23 & 70 & 65 & 74 \\
\hline $\begin{array}{l}\text { With superfic. } \\
\text { swellings } \\
\text { Without superfic. }\end{array}$ & 304 & 89 & 91 & 94 \\
\hline swellings & 778 & 73 & 78 & 83 \\
\hline
\end{tabular}

* Herd variation. 


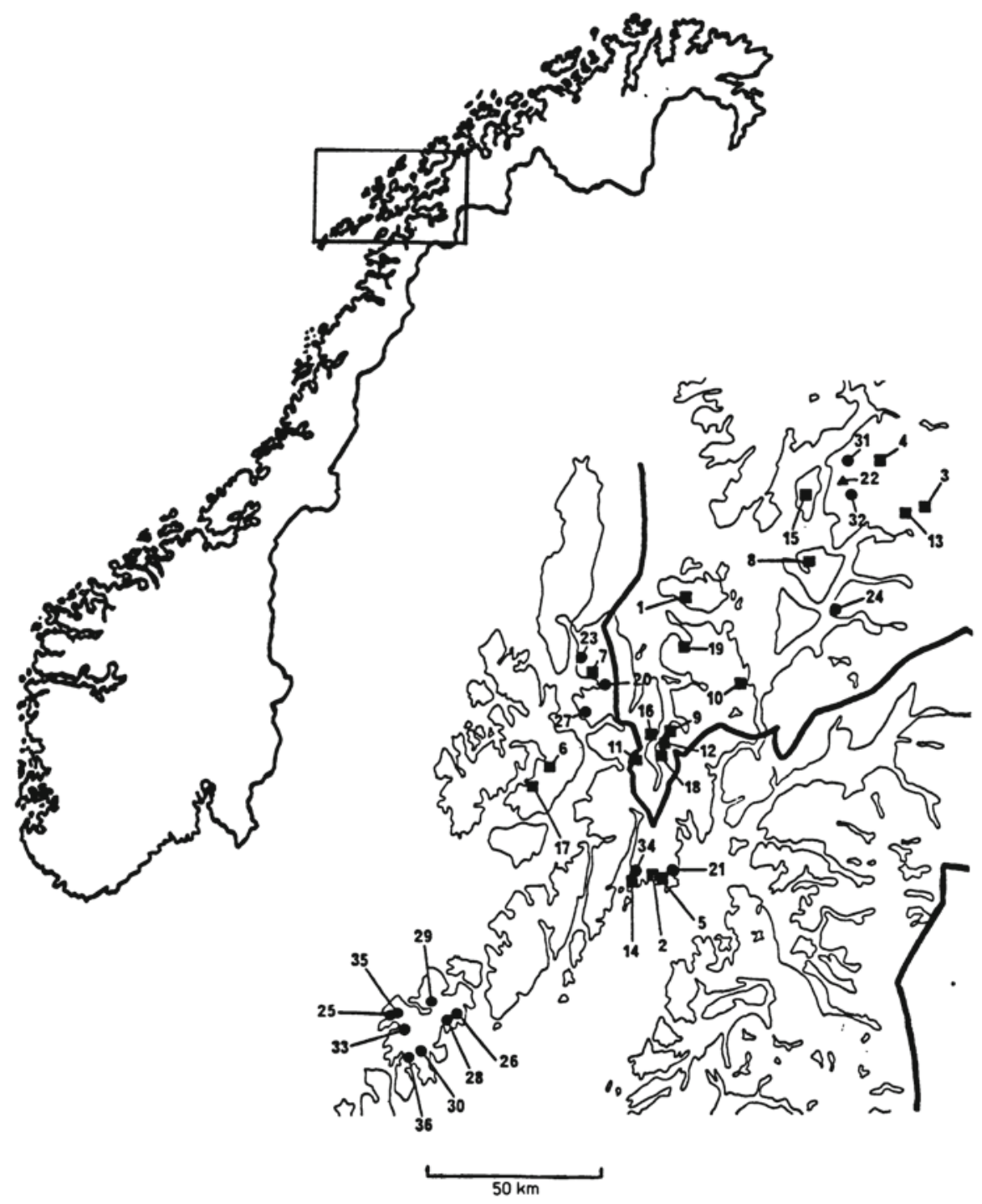

F i g r e 1. Geographical distribution of 36 goat herds surveyed for the presence of caseous lymphadenitis.

- Positive herd (Caseous lymphadenitis occurs).

- Negative herd (Caseous lymphadenitis does not occur).

$\Delta$ Uncertain positive herd. 
Non-infected herds (Herds 23-36)

The results of the clinical and serological examinations of animals from these herds are presented in Tables 1 and 2. These herds had no history of contact with animals from herds considered to be infected. Eight of these herds were located in a geographically isolated area while the remaining herds were located in regions in which infected herds were also present (Fig. 1).

Bacteriological examinations were carried out on pus samples from 3 animals from 2 herds. Staphylococcus aureus was isolated in pure culture from 2 animals and Corynebacterium pyogenes in mixed culture from 1 animal.

Sera from all animals with superficial swellings were negative in both BAT and HIT. A few of the animals were, however, seropositive, but all these had low antibody titres. One single animal was positive in both BAT and HIT.

\section{DISCUSSION}

Caseous lymphadenitis was diagnosed in all the herds in which the farmers reported the disease to occur, while the infection could not be demonstrated in herds in which the farmers reported that caseous lymphadenitis did not occur.

The present study indicated that transmission of the disease to non-infected herds takes place through contact with infected animals. Infected asymptomatic carrier animals exist and may transfer the disease.

Among the infected herds, the prevalence of seropositive animals was lowest in a herd in which the animals were kept separately in stalls. The present material is too small, however, to draw any firm conclusion from this finding.

Clinical and serological examinations indicated that caseous lymphadenitis was absent in 2 of the 3 "uncertain" herds (20 and 21). One of these herds (21) was, however, a member of a "breeding circle" together with 7 infected herds. There was thus a real risk that the disease could be introduced into this herd by infected breeding males.

In the third uncertain herd (Herd 22), caseous lymphadenitis was not definitely diagnosed. A single animal, however, had a high positive titre in BAT, and this animal may well have been infected with C. pseudotuberculosis. In this herd, many animals 
had been obtained from herds considered to be infected. There was thus reason to believe that this herd was in fact infected.

The non-infected herds had no contact with animals from infected herds and had probably avoided infection for this reason. The seropositive animals found in some of these herds had low titres, and the reactions can in all likelihood be regarded as false-positives. C. pseudotuberculosis was not isolated from any animal, though only a few animals were investigated bacteriologically. Sera from animals with superficial swellings in these herds were negative in both tests. This may indicate that the lesions were not caused by C. pseudotuberculosis.

Williams (1980) considered that abscesses caused by pyogenic bacteria such as $\mathrm{S}$. aureus and $\mathrm{C}$. pyogenes, as well as cysts and oedema should be included in the differential diagnosis of caseous lymphadenitis. The present study indicates that most superficial swellings in goats except swellings on the shoulder and chest are caused by C. pseudotuberculosis. In the non-infected herds, few animals had superficial swellings. In the infected herds, $94 \%$ of animals with such lesions which were examined serologically were positive in one or both tests. C. pseudotuberculosis was isolated from most of the superficial swellings found in animals from infected herds, which were examined bacteriologically. Ashfaq \& Campbell (1979) isolated C. pseudotuberculosis in 71 of 100 superficial abscesses in goats. In the present study, C. pseudotuberculosis was isolated from 25 out of 31 animals with abscesses from infected herds. Other bacteria were isolated from the remaining 6 animals, though 5 of these animals were seropositive. The abscesses in question were open, and it may well be that the primary cause was C. pseudotuberculosis with subsequent secondary infection/contamination by other bacteria after the lesions had ulcerated. C. pseudotuberculosis can be isolated in pure culture from closed and recently opened abscesses from goats with caseous lymphadenitis (Ashfaq \& Campbell 1980, Burrell 1981), while in older "open" abscesses. other bacteria can also be isolated (Ashfaq \& Campbell 1980).

In infected herds, the prevalence of animals with superficial swellings (26\%) was lower than the prevalence of animals which were positive in BAT $(81 \%)$ and in HIT (84\%). Burrell (1981) carried out clinical and serological examinations for caseous lymphadenitis in 2 dairy goat herds. In one herd, $21 \%$ of the lactating goats had superficial abscesses caused by C. pseudo- 
tuberculosis, while $62 \%$ and $55 \%$ of the animals in this herd were positive in the hemolysin inhibition test and double immunodiffusion test, respectively. Corresponding figures for the other herd were $28 \%, 60 \%$ and $79 \%$, respectively. In the present study, $83 \%$ of the animals with no demonstrable superficial swellings were seropositive in the infected herds. Clinical examination for superficial swellings combined with bacteriological investigation of any lesions found will thus fail to identify all infected animals. Lesions in internal organs and lymph nodes are common in animals with caseous lymphadenitis (Hein \& Cargill 1981), but cannot be detected on clinical examination. Moreover, small superficial swellings may be missed or disregarded, and lesions may perhaps sometimes heal leaving seropositive animals with no clinical signs. It is also probable that some animals become infected and produce antibodies against the bacterium without abscess formation.

In the present investigation, swellings on the shoulder and chest were considered to be granulomas resulting from vaccination against paratuberculosis. C. pseudotuberculosis is, however, sometimes isolated from such lesions in animals in infected herds (Holstad 1986b).

Most superficial swellings in animals in infected herds were located in, or close to, lymph nodes. Most animals (87\%) with such lesions had swellings in the head and neck region. Ashfaq \& Campbell (1979) found that $75 \%$ of goats with superficial abscesses had lesions in the head and neck region. Skin abrasions are reported to constitute the most important route of infection for C. pseudotuberculosis in sheep (Nagy 1976). Experimental infection, however, indicates that caseous lymphadenitis in sheep can be reproduced by placing $\mathrm{C}$. pseudotuberculosis on unbroken, recently shorn skin (Nairn \& Robertson 1974). Sharp edges on stall partitions probably lead to skin abrasions in the head and neck region in goats. Purulent material from open abscesses will contaminate the environment, and animals may become infected by contact with this material. Augustine \& Renshaw (1982) reported that C. pseudotuberculosis could survive for several days on nails and wood surfaces, and for several weeks in goat faeces and hay at $10-25^{\circ} \mathrm{C}$. Thus, in infected herds the bacterium will certainly be widespread in stalls. In the present study purulent material from abscesses was found on the feeding table in several herds, indicating the possibility of infection by the oral route. 
Abscess formation after oral infection seems, however, to be uncommon (Nagy 1976).

Some animals had superficial swellings in the udder and associated lymph node. C. pseudotuberculosis has been isolated from cases of mastitis in goats (Addo et al. 1980, Chaudhry et al. 1980, Yadav et al. 1982). In the present study some animals had superficial swellings localized in 2 or more different parts of the body. Awad et al. (1977) demonstrated enlarged superficial lymph nodes in 21 of 25 goats and in 11 of these animals more than 1 lymph node was affected. Superficial lesions on different parts of the body might have been a result of several independent infections or due to spread from a primary site of infection. Nagy (1976) infected sheep experimentally and demonstrated spreading of abscesses to several lymph nodes.

In the present study, the prevalence of male goats with superficial swellings and that of seropositive males were somewhat lower than those of female goats. The number of males was, however, small compared with the number of females, and it was therefore not possible to test the statistical difference, if any between the sexes with regard to the proportion of infected animals. Ashfaq \& Campbell (1979) found no difference in the prevalence of superficial abscesses in males and females. In the present study most males were kept separately in stalls. They had little contact with other animals in the herd when housed and were therefore probably less exposed to infection than females.

\section{REFERENCES}

Addo, P. B., C. N. Chineme \& F. I. A. Eid: Incidence and importance of chronic mastitis in Nigerian goats. Bull. Anim. Hlth Prod. Afr. $1980,28,225-231$.

Ashfaq, M. K. \& S. G. Campbell: A survey of caseous lymphadenitis and its etiology in goats in the United States. VM/SAC 1979, $74,1161-1165$.

Ashfaq, M. K. \& S. G. Campbell: Experimentally induced caseous lymphadenitis in goats. Amer. J. vet. Res. 1980, 41, 1789-1792.

Augustine, J. L. \& H. W. Renshaw: Survival of Corynebacterium pseudotuberculosis on common barnyard fomites. Proc. 3rd Int. Conf. Goat Prod. Dis., Tucson, Arizona 1982, p. 525.

Awad, F. I., A. A. El-Molla, M. E. A. Shawkat \& R. M. Arab: Isolation and identification of Corynebacterium ovis from sheep in Egypt. Egypt. J. vet. Sci. 1977, 14, 7-14. 
Buchanan, R. R. \& N. E. Gibbons: Bergey's Manual of Determinative Bacteriology. 8th ed., Williams \& Wilkins, Baltimore 1974, 1246 pp.

Burrell, D. H.: Caseous lymphadenitis in goats. Aust. vet. J. 1981, 57, 105-110.

Chaudhry, J. I., T. M. Khan, M. Shafique \& M. A. Basra: Studies on caprine mastitis. Pak. J. sci. Res. 1980, 32, 275-278.

East, N. E.: Chronic weight loss in adult dairy goats. Compend. contin. Educ. pract. Vet. 1982, 4, S 419-425.

Hein, W. R. \& C. F. Cargill: An abattoir survey of diseases of feral goats. Aust. vet. J. 1981, 57, 498-503.

Holstad, G.: Corynebacterium pseudotuberculosis infection in goats I. Evaluation of two serological diagnostic tests. Acta vet. scand. 1986a, 27, 575-583.

Holstad, G.: Corynebacterium pseudotuberculosis infection in goats V. Relationship between the infection and lesions resulting from vaccination against paratuberculosis. Acta vet. scand. 1986b, 27, $617-622$.

Lund, A., T. Almlid, H. J. Larsen \& T. Steine: Antibodies to Corynebacterium pseudotuberculosis in adult goats from a naturally infected herd. Acta vet. scand. 1982, 23, 473-482.

Marsh, H.: Newsom's Sheep Diseases. 3rd ed., Williams \& Wilkins, Baltimore 1965, p. 87-90.

Nagy, G.: Caseous lymphadenitis in sheep - methods of infection. J. S. Afr. vet. Ass. 1976, 47, 197-199.

Nairn, M. E. \& J. P. Robertson: Corynebacterium pseudotuberculosis infection of sheep: role of skin lesions and dipping fluids. Aust. vet. J. $1974,50,537-542$.

Renshaw, H. W., V. P. Graff \& N. L. Gates: Visceral caseous lymphadenitis in thin ewe syndrome: Isolation of Corynebacterium, Staphylococcus and Moraxella spp. from internal abcesses in emaciated ewes. Amer. J. vet. Res. 1979, 40, 1110-1114.

Ribe, H.: Personal communication.

Williams, C. S. F.: Differential diagnosis of caseous lymphadenitis in the goat. VM/SAC $1980,75,1165-1169$.

Yadav, J. S., K. N. Sharma \& P. O. Mathur: Note on bacteria associated with caprine mastitis and their antibiograms. Indian J. anim. Sci. 1982, 52, 465-467.

\section{SAMMENDRAG}

Corynebacterium pseudotuberculosis infeksjon hos geit II.

Prevalens av kaseøs lymfadenitt $i 36$ geitebesetninger $i$ Nord-Norge.

En unders $\varnothing$ kelse over forekomst av kase $\varnothing$ s lymfadenitt ble foretatt i 36 geitebesetninger i Nord-Norge. I alle besetningene ble det samlet inn opplysninger fra eierne om forekomst av sykdommen. I 35 besetninger ble dyr som var ett år eller eldre unders $\emptyset$ kt klinisk. I alle besetningene ble sera fra slike dyr unders $\emptyset \mathrm{kt}$ for antistoffer mot 
Corynebacterium pseudotuberculosis både ved bakterieagglutinasjonstest (BAT) og antihemolysintest (AHT).

Kase $\varnothing$ s lymfadenitt ble påvist i 19 besetninger hvor eierne opplyste at sykdommen forekom. De fleste eierne av disse besetningene opplyste at sykdommen hadde opptrådt i besetningen i mange år, og at den var blitt smittet med dyr fra besetninger hvor kase $ø$ s lymfadenitt var antatt å forekomme. Kliniske unders $\varnothing$ kelser ble foretatt $\mathrm{i}$ 18 av disse besetningene, og overfladiske hevelser ble påvist hos gjennomsnittlig $26 \%$ av de unders $\varnothing$ kte dyrene, med besetningsvariasjon fra 11 til $40 \%$. Ialt $87 \%$ av dyr med hevelser hadde slike lesjoner på hodet og halsen. Det var gjennomsnittlig $81 \%$ positive dyr ved BAT og $84 \%$ positive dyr ved AHT i disse 19 besetningene, med besetningsvariasjon fra 26 til 99 og 28 til $99 \%$ ved henholdsvis BAT og AHT. Prevalensen av serologisk positive dyr var lavest i en besetning hvor dyrene var oppstallet på bås.

I 16 besetninger ble kase $\varnothing$ s lymfadenitt ikke påvist. Eierne av disse 14 besetningene opplyste at de ikke hadde dyr med sykdommen og at besetningen ikke hadde hatt kontakt med dyr fra besetninger hvor kaseøs lymfadenitt var antatt å forkomme. I 2 av de 16 besetningene var eierne usikre på hvorvidt sykdommen forekom, og dyr i den ene av disse to besetningene hadde via bukkering kontakt med dyr fra besetninger hvor kaseøs lymfadenitt ble påvist. Det fantes få dyr med overfladiske hevelser i disse 16 besetningene, og alle dyr med hevelser var negative ved BAT og AHT. Få dyr var serologisk positive, men disse hadde lave titer.

I en nyetablert besetning hadde ett dyr høyt positivt titer ved BAT, men det var negativt ved AHT. De фvrige dyr var negative ved begge testene. I denne besetningen var det innkjøpte dyr fra besetninger med opplysning om forekomst av kaseøs lymfadenit og besetninger antatt fri for sykdommen.

(Received September 8, 1986).

Reprints may be requested from: Gudmund Holstad, the Department of Microbiology and Immunology, Norwegian College of Veterinary Medicine, Postbox 8146, Oslo Dep., Oslo 1, Norway. 